\title{
Farewell Spain: Kate O’Brien's Elegy to War-torn Spain
}

\section{Ute Anna Mittermaier}

\section{(2) OpenEdition \\ 1 Journals}

\section{Electronic version}

URL: http://journals.openedition.org/etudesirlandaises/3400

DOI: 10.4000/etudesirlandaises.3400

ISSN: 2259-8863

\section{Publisher}

Presses universitaires de Rennes

\section{Printed version}

Date of publication: 30 July 2013

ISBN: 978-2-7535-2673-0

ISSN: 0183-973X

\section{Electronic reference}

Ute Anna Mittermaier, « Farewell Spain: Kate O'Brien's Elegy to War-torn Spain », Études irlandaises

[Online], 38-1 | 2013, Online since 30 June 2015, connection on 20 April 2019. URL : http:// journals.openedition.org/etudesirlandaises/3400; DOI : 10.4000/etudesirlandaises.3400 


\title{
Farewell Spain: Kate O’Brien's Elegy to War-torn Spain
}

\author{
Ute Anna Mittermaier \\ Trinity College Dublin
}

Abstract

This paper analyses Kate O'Brien's representation of Spain in Farewell Spain (1937), drawing on unpublished material. It argues that Farewell Spain, written during the Spanish Civil War, amounts to a travelogue with a hidden political agenda. While O'Brien's explicit pro-Republican statements were clearly written in response to the one-sided representations of the Spanish conflict in Ireland and Britain, the author deliberately distanced herself from other war-commentators by embedding her political comments in a highly subjective, sentimental travel book.

Keywords: Kate O’Brien, Farewell Spain, Spanish Civil War, representation, political, Communist, Catholic.

\section{Résumé}

Cet article s'appuie sur des travaux non publiés pour analyser la représentation de l'Espagne par Kate O'Brien dans Farewell Spain (1937). Il montre que Farewell Spain, cuvre écrite pendant la guerre civile espagnole, se présente comme un journal de voyage dans lequel s'expriment des prises de position politiques. Si ces propos explicitement pro-républicains furent écrits en réponse à la présentation biaisée du conflit espagnol qui en fut faite en Irlande et en Angleterre, l'auteur prend délibérément ses distances par rapport à d'autres commentateurs de la guerre en intégrant ses commentaires politiques dans un livre de voyage très subjectif et sentimental.

Mots clés : Kate O'Brien, Farewell Spain, guerre d'Espagne, histoire, littérature du voyage.

Kate O'Brien's Farewell Spain, published in $1937^{1}$, was written between October 1936 and February 1937 under the shadow of the Spanish Civil War, which had broken out in July 1936 following the military uprising led by General Franco against the democratically elected Popular Front government of the Second Spanish Republic. As a result of the political troubles accompanying its genesis, the book represents a hybrid genre: though "inspired by the events of the Spanish Civil War, it is not exclusively a political book, any more than it is only

1. Kate O’Brien, Farewell Spain, (1937), London, House of Stratus, 2001. All page references will be to this edition, abbreviated as 'FS'. 
a travel book ${ }^{2}$." While O'Brien's travel account is based on several journeys to Spain undertaken in the 1930s, most of the events depicted in the book are drawn from her trip in $1935^{3}$. In addition, O’Brien includes reminiscences from the year 1922, when she worked as a governess for a wealthy Spanish family in a village outside the Basque city of Bilbao ${ }^{4}$, an experience which provided the inspiration for her third novel Mary Lavelle (1936). The journey traced in the book takes a circular form, starting in the northern province of Cantabria and leading - via Galicia and various Castilian cities - back up north to the Basque Country. Apart from factual information on Spanish cities, landscapes, architecture, paintings, and prominent figures from Spanish history (such as King Philip II, Teresa of Ávila, and El Cid), O’Brien's travelogue comprises personal impressions, amusing anecdotes, as well as comments on the ongoing conflict in Spain. Whereas O'Brien deliberately foregrounds the subjective and idiosyncratic nature of her record of Spain and ensures that her vivid portrayal of pre-war Spain outweighs her commentary on the Spanish Civil War, Farewell Spain in fact amounts to a travel book with a hidden political agenda.

The Spain of the early 1930s forming the subject of Kate O'Brien's travel book was troubled by socio-political tensions which the author could not help noticing during her visits. Since the Enlightenment, Spanish society had been divided along the lines of class and property, liberalism vs. conservatism, secularism vs. Catholicism, and centralism vs. regional nationalisms. Since neither the Spanish Right nor the Left represented a uniform political faction with a common ideology or agenda, neither of them succeeded in maintaining their hold on power for long. Thus, the first three decades of the $20^{\text {th }}$ century saw the establishment of a military dictatorship under General Primo de Rivera with King Alfonso XIII's consent (1923-30), the escape of the dictator and the king into exile, the procla-

2. María Isabel Butler de Foley, "Each Other's Country: Some Twentieth Century Irish and Spanish Writers", Logan J. (ed.), With Warmest Love. Lectures for Kate O'Brien. 1984-1993, Limerick, Mellick Press, 1994, p. 23.

3. Mary S. Vásquez, "Loving Tourist in Kate O’Brien”, Revista Monográfica, n 12, 1996, p. 112.

4. Lorna Reynolds, Kate O’Brien. A Literary Portrait, Gerrards Cross, Colin Smythe, 1987, p. 36. O’Brien described her time as a governess in northern Spain in at least two lectures and her unpublished essay "My Spain": Lecture to the Association of Professional and Business Women in Canterbury of 10 March 1972, Typescript, University of Limerick Collection of Kate O’Brien papers; Lecture to the Claremorris Countrywomen's Association, c. 1957, Holograph, and "My Spain”, Holograph, c. mid-1960s, Northwestern University (Chicago) Collection of Kate O'Brien Papers. In the latter, she said that she left for Northern Spain "early in September” 1922 and stayed there "for about ten months"; she had no Spanish at the time of her arrival and "was about as ignorant and unconcerned about the country called Spain as possibly [she was] now [i.e. in the 1960s] about Mars" (p. 1-2). But, as Walshe and Mentxaka have noted, the contradictory statements concerning the exact dates of O'Brien's stay with the Areilza family by both the author herself and her friends and critics make it impossible to establish the exact dates and duration of O'Brien's stay with the Areilzas. Eibhear Walshe, Kate O'Brien. A Writing Life, Dublin, Irish Academic Press, 2006, p. 30; Aintzane Legarreta Mentxaka, Kate O'Brien and the Fiction of Identity. Sex, Art and Politics in Mary Lavelle and Other Writings, Jefferson, McFarland\&Company, 2011, p. 209). I am grateful to Eibhear Walshe for advising me on the accessibility of the unpublished Kate O'Brien papers held at the Northwestern University (Chicago). 
mation of the Second Spanish Republic, and the victory of the left-wing parties in the 1931 elections. As the Socialist-dominated government's social and territorial reforms went too far for its political opponents but fell short of meeting the expectations of its more radical adherents and thus led many frustrated Anarchists to abstain from voting, the general elections of 1933 were won by the centre - and right-oriented parties. The new reactionary government's repeal of its predecessors' reforms triggered a poorly coordinated leftist revolt in Catalonia and Asturias in October 1934, which was violently put down by the Spanish army. In the following months the increasing polarisation and radicalisation of Spanish society led to political assassinations, church burnings, and a series of workers' strikes in different parts of the country. When the 1936 elections returned the left-wing parties to power with a narrow majority, they formed an unstable Popular Front coalition composed of Socialists, Communists, and Anarchists. The assassination of the conservative politician Calvo Sotelo by the Republican police provided the final trigger for the army's insurrection on 17 July 1936.

The military insurgents were enjoying the moral and material support of Spain's right-wing forces comprising conservative Monarchists as well as Fascist Falangists and came to be collectively referred to as the "Nationalists" in the Anglophone press 5 . Aided by German aircraft and Italian artillery, they had expected a swift victory. However, owing to the generous arms supplies from the Soviet Union and the readiness of thousands of civilians - including Basque and Catalan nationalists defending their claim to political autonomy as well as hundreds of volunteers from abroad joining the "International Brigade" - to take up the cudgels for the Republican government, the military putsch turned into a devastating civil war which would only end with a Nationalist victory on 1 April 1939. The Non-Intervention Agreement, which had been signed in August 1937 by twenty-four member-states of the League of Nations (including the Irish Free State) on the instigation of Britain and France to contain the conflict in Spain, had remained virtually ineffectual given that it was persistently violated by Fascist Germany and Italy and the Communist Soviet Union offering military assistance to the warring factions ${ }^{6}$.

5. In line with most of the Anglophone (academic) accounts of the history of the Spanish Civil War I use the terms 'Nationalists' and 'Republicans' to refer to the supporters of Franco and the defenders of the left-wing government of the Second Spanish Republic respectively. To avoid confusion of the 'Nationalists' with the Basque and Catalan nationalists, who largely fought on the Republican side, I follow common practice in spelling the latter with a lower case ' $n$ '. As an alternative way of preventing confusion, Mentxaka has made the useful suggestion to use the term 'the nationals' (derived from the Spanish term 'los nacionales') for the Francoist army. Aintzane Legarreta Mentxaka, op. cit., p. 47.

6. Antony Beevor, The Spanish Civil War, London, Orbis, 1982, 14 sq.; Paul Preston, A Concise History of the Spanish Civil War, London, Fontana Press, 1996, 10 sq. 
When Kate O’Brien finished Farewell Spain in February 1937, the Republicans still seemed to stand a chance of winning the war. Referring to the recent fall of the Basque city of Irún to Franco's troops ${ }^{7}$, O’Brien describes herself as a "sentimental traveller" and an "escapist" seeking refuge in the past since the present is too painful to contemplate and the future prospects are bleak, with new war-clouds gathering rapidly over Europe. Farewell Spain is thus pervaded by a sense of foreboding, accompanied by a spirit of nostalgia for an earlier, happier time when it was still possible to take a leisurely stroll in Spanish cities that had now become targets of Nationalist air raids. Despite her stated intention in the opening chapter to "draw the blinds again and invite our old cosiness" and to "praise personal memory, personal love" after having predicted the downfall or cataclysmic transformation of "European society" in its "next crisis", however, the author intersperses her travel account with frequent references to battle-scenes of the Spanish Civil War, which attest to her inability to prevent unpleasant thoughts of the conflict from creeping into her mind. The elegiac, sentimental tone of her book comes out particularly strongly in her chapter on Madrid, which was under siege from Nationalist forces at the time of writing:

I approach Madrid now as never before - in a mood of weary sadness. Frequently as I write these casual reminiscences I feel what I suspected when I began them - that I am indeed a Nero sucking pleasantly at happiness given me so short a time ago by a country now in agony. And as Madrid, the Madrid of only one year past, comes rippling out untidily and showily to meet me along the dusty road from Los Pinares, I feel self-conscious before my own sentimentality and reluctant to go forward in search of what is lost ${ }^{10}$.

That the writer's genuine concern for Spain's fate derives from her intense passion for this country becomes clear from her paeans to "empty, blond, austere $^{11}$ " Castile and the Spanish people. O'Brien ascribes excellent manners, a healthy balance between pride and courtesy, gregariousness, good taste, commonsense, sobriety, individualism, and gravity in the sense of dignity and composure $^{12}$ to the Spaniards. However, the author expresses her love for Spain most explicitly in the book's penultimate paragraph:

\author{
7. FS, p. 5. \\ 8. FS, p. 1-2. \\ 9. FS, p. 3-5. \\ 10. FS, p. 83. \\ 11. FS, p. 101. \\ 12. FS, p. 29, 32, 39, 122-24, 153.
}


Fatal attraction between persons is an old poets' notion that some of us still like to believe is possible and occasional, though not probable and Spain seems to me to be the femme fatale among countries. [...] So true is this that I have hardly seen any other countries. Always I go back over the Pyrenees. My love has been long and slow - lazy and selfish too, but I know that wherever I go henceforward and whatever I see I shall never again be able to love an earthly scene as I have loved the Spanish. Except some bits of Ireland, bits of home. But that is different. Though Ireland is as beautiful as any country on earth, I am native to her, and therefore cannot feel the novel thrill of her attraction. One does not mix up the love one feels for a parent with the infatuations of adult life. And with Spain I am once and for all infatuated ${ }^{13}$.

In this frank declaration of love O'Brien effectively personifies Spain and casts herself in the role of the suffering lover temporarily separated from the object of her infatuation on account of the civil war and anxious about its well-being. Since she cannot physically come to Spain's assistance, she uses her travel book to wage a verbal battle in its defence ${ }^{14}$. Indeed, throughout Farewell Spain, Kate O'Brien comes across as a passionate Hispanophile jealously guarding her favourite foreign country's reputation. From the beginning, she feels the need to defend Spain against ignorant, narrow-minded tourists, who, having expected to find the hot, sunny poster-card version of Spain promoted by the tourist agencies, are disappointed with the 'real' Spain they encounter on the northern coast. The typical tourists O'Brien has in mind are members of the English working class, who arrive in hordes hoping to bask in the sun and get "as brown as the Spaniards ${ }^{15}$ ", make no attempt to mix with the Spanish population, take no initiative to explore the country, and - failing to get the "immediate pleasure" and "picturesque thrill" they expected from their precious two weeks of holidays - are "reinforced in their unfortunate national smugness ${ }^{16 ”}$. A personal encounter with an English couple rudely bursting out laughing at the exhibits in the Escorial Palace leads O'Brien to decry the lack of respect which the English - "an imperial race" taking pride in their "genius for pageantry ${ }^{17}$ "

13. FS, p. 155.

14. This point has also been made by Vásquez, op. cit., p. 115.

15. FS, p. 20.

16. FS p. 20. In her fairly contemptuous remarks on the English working-class tourists' idle search for pleasure in Spain, O’Brien expresses what Fussell has aptly referred to as "tourist angst", i.e. the need of experienced, educated and individualistic travellers to distance themselves from the broad mass of supposedly ignorant, herdthinking tourists. Cf. Paul Fussell, Abroad. British Literary Travelling Between the Wars, Oxford, OUP, 1980, p. 49. According to Carr, "dismay at the democratisation of travel was widely shared among travel writers [of the modernist period], many of whom shared the same suspicion of popular travel that modernists exhibited towards popular culture in general". Cf. Helen Carr, "Modernism and Travel (1880-1940)", Hulme P. and Youngs T. (eds.), The Cambridge Companion to Travel Writing, Cambridge, CUP, 2002, p. 79.

17. FS, p. 114-15. 
- show for foreign cultures. Although she desists from making any more explicitly anti-imperial, Anglophobe statements and from foregrounding her Irish nationality, O'Brien conveys the impression that the Irish have a better understanding of Spanish culture than the British - not least because of their common Catholic religion. Thus, she asserts that, while King Philip II's allegedly pathological obsession with death "makes Protestants shudder ${ }^{18}$ ", it can only draw a smile from Catholics, who are less afraid of death. Moreover, she suggests that the special affinity between the Spanish and the Irish also manifests itself in a similar sense of humour: while "Madrid's conversation is reminiscent of Dublin", the "horseplay" and "ribaldry" of the people of Vizcaya reminds the author "particularly of the talk of [her] native Munster ${ }^{19}$ ". Finally, O'Brien also attributes her own passion for Bilbao, then an industrial city attracting few tourists, to her Irish background. Unlike an English acquaintance, who disliked "Bilbao's mud, and passions just under the skin," she took to Bilbao exactly because of these two special features: "Mud was an ordinary matter in Ireland when I was young, and passions - so long as they be not sexual are our familiars ${ }^{20}$." Essentially, all these hints at a special bond between the Irish and the Spanish serve O'Brien to establish herself as a real connoisseur of Spain who, as a Catholic Irishwoman having lived in Spain for a year and speaking the native language, is in a better position to judge the country and its people fairly than other foreign commentators.

Consequently, it is hardly surprising that O'Brien repeatedly disagrees with travel- and guidebook writers who in her opinion sully Spain's reputation by perpetuating old clichés. Whereas she occasionally refers her readers to guidebooks for detailed descriptions of famous tourist attractions, she repeatedly dismisses the authors' use of certain adjectives which in her opinion fail to do justice to the object of description. For example, she takes exception to Théophile Gautier's banal description of Toledo's "gold" sandstone buildings as "saffron and orange"21" and the French Blue Guide's portrayal of Ávila as "sombre et froid2". Besides, she blames the negative international image of King Philip II as a megalomaniac tyrant not least on guidebooks causing visitors to the King's palace to see "only what they came out primed to see - the dreadful chef-d'œuvre of an unpleasant man ${ }^{23}$ ". As O'Brien concedes, "it seems as if the guidebook writers and [her] can never agree ${ }^{24}$."

\footnotetext{
18. FS, p. 107.

19. FS, p. 146.

20. FS, p. 143.

21. FS, p. 56.

22. FS, p. 77.

23. FS, p. 104

24. FS, p. 131.
} 
Apart from prejudiced tourists and unfair guidebook-writers, O’Brien apparently detests all encroachments of modernity on her beloved Spain. She deplores the omnipresence of loudspeakers and radios in Spanish towns and the erection of ugly, functional buildings at odds with their natural surroundings ${ }^{25}$. Furthermore, she considers it unfortunate that Spanish women spoil their natural good looks by putting on layers of garish make-up and dyeing their hair blonde in imitation of their favourite Hollywood stars ${ }^{26}$. While the author grants the generally "good taste" of the Spaniards, she dismisses all Spanish attempts at making private homes or hotels look modern as inevitable failures ${ }^{27}$. Still, as O'Brien herself points out, it would be wrong to simply take her for a "'ye olde' fan, an arty-and-

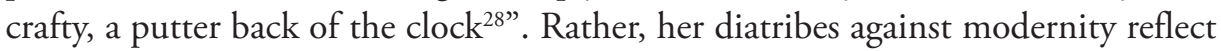
sentiments and concerns shared by many other travel writers of the late modernist period, i.e. "a certain world-weariness, springing from disillusionment with European civilisation" and the fear that under the homogenising effect of economic and cultural internationalisation individual nations were losing their "distinctive otherness ${ }^{29 "}$.

What is less easy to explain, let alone excuse, than O'Brien's antipathy to modernity, is her repeatedly stated contempt for the Moors, whom - together with internationalism - she accuses of having corrupted 'Spain's native taste':

The Moor long ago imperilled Spanish judgment with his arty-and craftiness. Imperilled and infected, but mercifully did not dominate. Still, his legacy remains a menace, and I, for my part, detest all signs of the Moor in Spain ${ }^{30}$.

On the one hand, O'Brien's repeatedly stated dislike for Moorish culture and architecture seems to have been heartfelt - as her friend Lorna Reynolds confirms in her biography of the writer:

[O'Brien] had no interest in, in fact, an active dislike of Moorish Spain. [...] "Let anyone who wants to interest himself in the Arab contribution to Spain, do so", she would say. But one could not ask her to do so. Christian Spain was what concerned her ${ }^{31}$.

25. FS, p. 29, 35 .

26. FS, p. 119.

27. FS, p. 124.

28. FS, p. 29.

29. Helen Carr, op. cit., p. 81. Similarly, Michael Cronin argues that "Kate O'Brien's stated aversion to the modern in her travel accounts is more to do with a prescient sensitivity to the dramatic and imminent changes in the societies she describes rather than a reactionary, atemporal nostalgia." Michael Cronin, "Moving Pictures: Kate O’Brien's Travel Writing”, Eibhear Walshe (ed.), Ordinary People Dancing, Cork, Cork UP, 1993, 146.

30. FS, p. 124.

31. Lorna Reynolds, op. cit., p. 105. 
This is all the more remarkable since O'Brien's dismissive comments on southern Spain were not based on first-hand-knowledge of the region: in the 1960s she admitted in an unpublished essay that "in years of going back and back to [northern and central] Spain, [she had] never yet set foot in Catalonia or Andalucía, in Aragon [sic] or Valencia ${ }^{32}$." On the other hand, though, O'Brien's antipathy to Spain's Arabic traces can also be interpreted as a manifestation of her disapproval of numerous foreign, particularly French, British, and American, accounts of Spain emerging since the Romantic period in which Andalusia and its 'exotic', Oriental Moorish heritage were glorified, while the later cultural achievements of Catholic Spain were virtually ignored. That is, O'Brien's exclusion of the Moorish-influenced southern and eastern provinces from both Mary Lavelle and Farewell Spain possibly reflects not only her aversion to Moorish Spain, but also her endeavour to counteract previously dominant misrepresentations of Spain as an entirely un-European and un-Christian country. Aintzane Legarreta Mentxaka has further suggested that O'Brien's belief in Castile's superiority to the rest of Spain stemmed largely from her reading of the writers of the 'Generación del '98', including Miguel de Unamuno and Pío Baroja, who hailed Castile as the heart of the 'real', old Spain that needed to regenerate itself after the loss of its main colonies in the Cuban War through introspection and the formation of "an authentic Spanish identity" built on "core values" such as "austerity, individualism, moral integrity, and communion with the landscape ${ }^{33 "}$. With particular regard to Farewell Spain, however, O'Brien's anti-Moorish statements must be seen in the context of the Spanish Civil War, in which Muslims from Spanish Morocco fought in large numbers on the Nationalist side ${ }^{34}$. As Vásquez has noted, "[g]iven the role that Moorish troops played in quite a number of military actions and civil conflicts in Spain - and, indeed, in the Spanish Civil War - it seems likely that contemporary reality fires O'Brien's animosity to the Moorish legacy35".

In the eighth chapter of her Spanish travelogue O'Brien professes her support for the Republican government in unequivocal terms:

I am not a Communist, but I believe in the Spanish Republic and its constitution, and I believe in that Republic's absolute right to defend itself against military Juntas, the Moors and all interfering doctrinaires and mercenaries. And naturally I believe, as one must, in the Spanish

32. Kate O’Brien, “My Spain”, op. cit., p. 9.

33. Aintzane L. Mentxaka, op. cit., p. 35.

34. Franco's Moorish soldiers "had originally been raised to hold down Spain's Moroccan Protectorate, and an estimated 60,000-70,000 served in Spain during the Civil War" (Tom Buchanan, The Impact of the Spanish Civil War on Britain: War, Loss and Memory, Brighton, Sussex Academic, 2007, p. 10).

35. M. S. Vásquez, op. cit., p. 120. 
Republic's right to establish itself communistically, if that is the will of the Spanish people ${ }^{36}$.

As this declaration of her pro-Republican sympathies shows, the author knew about the strong Moorish presence in Franco's army and was therefore prone to consider the Moors collectively as the enemies of the embattled leftist Republic which she vociferously defended in her book. As an alert observer of the contemporary political scene of Europe in general, and of her home country in particular, O'Brien, who had been living in London since the early $1920 \mathrm{~s}^{37}$, would have also known that, contrary to the situation in Britain, public opinion in Ireland was overwhelmingly pro-Franco. Approximately 700 volunteers followed General O'Duffy's call to form a pro-Nationalist Irish Brigade and made Ireland "the only country to send a significant force of genuine volunteers [...] to fight for the rebels $^{38 "}$. They vastly outnumbered the 150 to 200 Irishmen who joined the proRepublican International Brigades. This can mainly be attributed to the powerful opinion-shaping influence of the Irish Catholic Church and the conservative press, which presented the Spanish Civil War as a religious battle between Franco and his 'crusaders' on the one side and the 'godless Reds' plotting to wipe out the Spanish clergy and transform Catholic Spain into an atheistic Soviet republic on the other ${ }^{39}$. Arguably, it is exactly because O'Brien is aware that "much Catholic opinion backed Franco" that "she cannot go beyond Christendom's traditional mistrust of the Crafty Moor, the Dark Other", while she is "generous in pointing out the basic similarities between Catholicism and Communism ${ }^{40}$ ". In fact, she exploits this deeply rooted negative image of the Moors to win her (Christian) readers' sympathy for Spain's beleaguered Popular Front coalition. In her effort to depict the war as a struggle of "Franco's fellow-countrymen" defending their legitimate left-wing government against self-important Spanish generals assisted by "alien" invaders ${ }^{41}$, O'Brien places much greater emphasis on the Muslim North African than the Fascist German and Italian contribution to Franco's war effort. Without stating her intention explicitly, O'Brien is effectively rebutting Nationalist propaganda hailing Franco and his followers as the Saviours of Christendom ${ }^{42}$.

\section{FS, p. 84 .}

37. Adele Dalsimer, Kate O'Brien: A Critical Study, Dublin, Gill and Macmillan, 1990, p. 6.

38. John Newsinger, "Blackshirts, Blueshirts, and the Spanish Civil War", Historical Journal, n 44, autumn 2001, p. 840 .

39. For detailed discussions of the public reaction to the Spanish Civil War in Ireland and the military involvement of Irish volunteers on both sides in the conflict see: Fearghal McGarry, Irish Politics and the Spanish Civil War. Cork, Cork UP, 1999; Robert Stradling, The Irish and the Spanish Civil War. 1936-39. Crusades in Conflict, Manchester, Mandolin, 1999.

40. Michael Cronin, op. cit., p. 145.

41. FS, p. 133.

42. Only once does O'Brien explicitly express her disagreement with pro-Nationalist papers: after stating that the Communist principle "From each according to his ability to each according to his need [...] was also Saint 
O'Brien's highlighting the absurdity of the ongoing siege by Republican forces of the Nationalist-held Alcázar of Toledo, during which "Spaniards [were] holding a Moorish fortress against Spaniards for the advancing, returning Moor" serves the same purpose as describing herself as "Catholic in all [her] blood", and distancing herself clearly from Communism while acknowledging that its "root inspiration [...] is simply the old, old generosity and decency of a few of the world's saints ${ }^{433}$ ": namely, to demonstrate that - even as a devout Catholic - the writer is justified in siding with the allegedly anticlerical 'Reds' given that the Nationalists' alliance with North African Muslims discredits them as 'Catholic Crusaders'. In stressing Franco's heavy reliance on Moorish soldiers for his allegedly 'Catholic' crusade, O'Brien was actually employing a trump card much used in Republican propaganda ${ }^{44}$, but she chose not to acknowledge this, lest her personal and 'sentimental' travel book be read as a manipulative political tract.

Likewise, it is probably in response to Nationalist propaganda whipping up an anti-Communist hysteria in Ireland with lurid stories of anticlerical outrages in Republican Spain that O'Brien finds it necessary to stress that she laments the church-burnings mainly committed by Spanish Anarchists and "hold[s] all war to be barbarous and ignoble ${ }^{45}$ ". Although she considers herself "a pacifist," she finds that "one's pacifism is indeed pressed hard by natural rage and sympathy" in the face of a "war such as General Franco's, openly aimed at the murder of every democratic principle, and for the setting up of his little self as yet another Mussolini ${ }^{46 "}$. The author's praise for the 1931 Constitution of the Second Spanish Republic amounts to an indirect condemnation of the international non-intervention pact:

[...] though it has always been Spain's way to play a lone hand - even she can be allowed to do that no longer, and in any case, say only Spaniards were fighting this war [,] it is being fought for an issue which is everyone's immediate concern everywhere. It is a war waged by the forces of militaristic absolutism against democracy. However anti-Communist you may be and however you may deplore the burning of churches or the penalising of the traditional religion of Spain, you cannot, if you take the

Teresa's eternal cry", she surmises that "it is probable - pace the Universe and the Catholic Herald - that she, indomitable fighter, would have been today on the side of Valencia and Madrid" (FS, 152).

43. FS, p. 99, 65, 151.

44. As Buchanan points out, "the left ruthlessly exploited the racial scare associated with General Franco's use of Moorish soldiers to spearhead his invading army." The Moors "were singled out" because they were Muslim and 'anti-Christ', but "most significantly, [...] because they were 'black" and, by (racist) implication, uncivilised and savage. "Such cheap propaganda [...] doubtless served a useful purpose in building popular sympathy for Republican Spain” (Tom Buchanan, op. cit., p. 11-13).

45. FS, p. 149, 152.

46. FS, p. $150-51$. 
trouble to read the 1931 Constitution, deny its dignity, justice, humanity, efficiency and natural idealism ${ }^{47}$.

Her conviction that the war in Spain represents "a key struggle for the democratic principle ${ }^{48}$ " allows her to back the Republican army despite her awareness that it is increasingly coming under the control of non-Spanish Communist doctrinaires ${ }^{49}$. Whereas she "dread[s] [...] the Communistic insult to individualism and spiritual freedom ${ }^{50}$ ", O'Brien is confident that in the case of a Republican victory Spain will not become a Soviet satellite state, for the Spaniards' allegedly strong Catholic faith and individualism make it "unlikely that the regimentation of Russian Communism could work at all in Spain ${ }^{51}$ ".

Still, O’Brien seems to consider a Communist regime in Spain preferable to a Fascist dictatorship by Franco. As mentioned, she believes that Communism, at least in theory, shares certain principles of solidarity with Christianity ${ }^{52}$; by contrast, she sees Fascism as "the glorification of one silly nationalism above another" and "the assertion of one bully's ego, and his claim to patronise and allocate the destinies of millions of his fellows, without the faintest reference to their egos and their claims ${ }^{53}$. As Mary O'Neill has observed in her preface to the 1985 Virago edition of the book, it is significant that O'Brien finished writing Farewell Spain at the beginning of 1937, "when the cause of the elected Republican government seemed clear cut and simple $e^{54 "}$. After May 1937, when the Communists violently asserted control over their more radically left-wing opponents (Anarchists and Trotskyists), it was much harder to argue that a Republican victory would guarantee the survival of democracy in Spain.

O'Brien's belief that the Spanish Civil War has international significance as a potential prelude to a worldwide struggle against Fascism ${ }^{55}$ partly explains why she says little on the specifically Spanish socio-political problems precipitating the conflict. She briefly refers to the workers' strikes, agrarian unrest, and nationalist agitation in Asturias, the Basque Country, and Andalucia she witnessed in the pre-war years, but she does not explore Spain's feudal agricultural system ${ }^{56}$, the impoverishment of rural and industrial workers, and the Basques' and Catalans' struggles for autonomy as central causes of the Spanish Civil War. Apart

47. FS, p. 149-50.

48. FS, p. 152.

49. FS, p. 84.

50. FS, p. 151.

51. FS, p. 153.

52. FS, p. 151.

53. FS, p. 151.

54. Mary O’Neill, “Introduction”, Farewell Spain by Kate O’Brien, London, Virago, 1985, p. XIII.

55. FS, p. 149.

56. FS, p. $24,45,86,150$. 
from O'Brien's intention to highlight the international dimension of the war in Spain, another reason for her relative silence on the various domestic issues underlying the conflict might have been her wish to preserve the aesthetic-literary character of her travel book. Thus, she decides against elaborating on her disagreements with non-Spanish Communist doctrinaires because this would "distort the whole concept and purpose of this book ${ }^{57}$. The indicated, but unspecified official 'purpose' of Farewell Spain seems to be the recording of the personal memories of a glorious, peaceful Spain by a lover of the country fearing its complete destruction in warfare. In addition, however, in writing the book O'Brien arguably pursued a second, subtly concealed goal: namely, to win her readers over to the side of the Spanish Republicans. By keeping her political analysis as short as possible and embedding it seemingly casually in her travelogue, she was more likely to reach and influence a wide, susceptible readership than by writing an overtly polemical pro-Republican tract which would have merely allowed her to preach to the already converted.

O'Brien's tight-lippedness on peripheral nationalisms in Spain, however, cannot be fully explained with her intention to present the Spanish Civil War as a war with international repercussions or to lend her book a seemingly apolitical character. With respect to British commentators on the conflict, Mackey notes that whereas " $t \mathrm{t}]$ he class war, with its religious dimensions, was well understood", "the regional separatist war was not ${ }^{58 "}$. In O'Brien's case, it was not so much that she was ignorant of the nationalist struggle; rather, the fact that she only refers to Basque nationalism in passing, does not even mention Catalan nationalism, and desists from capitalising on the links between the Irish and the Basque and Catalan struggles for independence (merely alluded to in Mary Lavelle) in order to win her Irish readers' sympathies for the pro-Republican Basques and Catalans, suggests that she took little interest in regional nationalisms. This impression is reinforced by her failure to explicitly foreground the support of the famously pious Basque Catholics for the Republic and the killings of Basque priests by the Nationalists - a card which was just as overplayed by Republican propagandists as the recruitment of Moors for Franco's army to debunk the myth of the Nationalist's 'Catholic Crusade'. Significantly, she does not follow a general trend among British travel writers to grant the Basques a distinct national identity by endowing them with specific qualities - such as fervent Catholicism, egalitarianism, and industriousness - setting them apart from the rest of the Spanish popu-

57. FS, p. 84 .

58. Theresa M. Mackey, "Giving a Damn: An Interdisciplinary Reconsideration of English Writers' Involvement in the Spanish Civil War", CLIO: A Journal of Literature, History and the Philosophy of History, n 27, Fall 1997, p. 103. 
lation ${ }^{59}$. Indeed, it follows logically from O'Brien's aforementioned subscription to the Castilian centralism of the 'Generación del '98' that she also shared the opposition of these writers to the regional separatist movements in the Basque Country and in Catalonia. Presumably it is because O'Brien was aware that "Basque support for the Republic was largely motivated by ambitions of regional autonomy ${ }^{60} "$ that she chose not to lend it too much weight. Her general distrust of nationalisms as breeding hatred between the different nations of the world manifests itself in her cynical statement in Farewell Spain that "[s]cience, if sane survival be indeed her aim for human life, will do well [...] to follow ruthlessly all the lines that lead from it to a smooth international uniformity, trampling out the romantic differentiations through which history, or our conception of it, has led us to the twentieth-century shambles ${ }^{61}$ ".

Yet, O'Brien had not only "an allergy to orthodox nationalism", but also "a deep dislike of political institutions, activist organizations, and dogmatic political movements" in general ${ }^{62}$. The author was no political radical, for neither in Farewell Spain nor elsewhere did her left-wing sympathies take her as far as to commend the Anarcho-Syndicalist and Communist call for a social revolution providing the collectivisation or just redistribution of land and property. Rather, her "obsession" with "individuality ${ }^{63}$ " made her conceive of anarchism as the political system, or rather 'non-system', which granted individual citizens the greatest degree of personal freedom. In Farewell Spain she described "absolute anarchy" as "Heaven on earth", but "an impossible condition of life ${ }^{64 "}$. Therefore, instead of demanding the total abolition of the Spanish state, she compromised by backing the democratically elected Popular Front government and hoping that "with time and luck the Peninsula [would] perhaps resolve itself into a loosely-linked federation of small, democratic states, all governed for external purposes from a centre, but internally run on regional, distributive principles ${ }^{65}$. In her 1936 novel Mary Lavelle, O’Brien had similarly presented anarchism as an admirable, idealistic political ideology through her sympathetic portrayal of Spanish characters combining anarchist leanings with Christian ethics. The heroine's employer

59. Brian Shelmerdine, "The Experiences of British Holidaymakers and Expatriate Residents in Pre-Civil War Spain”, European History Quarterly, n³2, fall 2002, p. 384. Already in her 1936 novel Mary Lavelle O’Brien made conspicuously little of the specifically Basque setting of her novel. Her main characters are consistently referred to as 'Spanish' rather than 'Basque' and speak Castilian among themselves. The term 'Basque Country' is only rarely used and usually replaced with 'Spain' or phrases like "the north of Spain” or "[Don Pablo's] own region of Spain”. Kate O’Brien, Mary Lavelle, London, Virago, 2000, p. 49, 54.

60. Brian Shelmerdine, op. cit., p. 384.

61. FS, p. 3.

62. Aintzane Legarreta Mentxaka, op. cit., p. 139, 217.

63. Aintzane L. Mentxaka, op. cit., p. 219.

64. FS, 23.

65. FS, 153. 
Don Pablo, while being "Jansenist [...] by tradition, [...] is intellectually an Anarchist ${ }^{66 "}$. He seems to have inherited this seemingly contradictory Weltanschauung from his father Don Juan, who was "Christian, cultured, somewhat Jansenistic, but profoundly a Spaniard - that is, convinced to the last drop of his blood of the absolute dominion of personality over system ${ }^{67 "}$. Similarly, Don Pablo's only son Juanito is "Communistically inspired as his father had never been, but [...] unable to escape his personal faith in the Catholic Church ${ }^{68}$ ". Unlike his contemplative and resigned father, Juanito is a revolutionary political activist with the utopian plan to establish a Communist "slave-state" as a transitional system to Anarchism in Spain ${ }^{69}$. His trust that future generations will overthrow the slave- state is based on his faith in the Spanish people's strong Catholic faith and individualism ${ }^{70}$. But Juanito realises that "[he is his] own political party", and neither his wife nor his father believe that his quixotic theories can ever be realised ${ }^{71}$. Thus, both in Mary Lavelle, composed in 1935 against the background of growing radicalisation on the Spanish Left and Right, and in Farewell Spain, written in the winter of 1936/37, when the tensions had already exploded into a bloody civil war, O'Brien promoted anarchy as a noble, yet unachievable political goal. In Mary Lavelle she sought to counteract the widespread negative image of the anarchists as violent, atheistic thugs by portraying Spanish anarchists as cultivated, Christian idealists looking for the best way to combine social justice with respect for the individual's need for personal freedom. In Farewell Spain, O'Brien again reacted to anti-anarchist propaganda by insisting on the sanity of anarchist beliefs, while her defence of the Popular Front government implies her approval of the Spanish anarchists' pragmatic decision to abandon its traditional abstentionist policy and join forces with the Republican army to stop the Fascist advance.

Despite her unequivocal declaration of support for Spain's left-wing government, O'Brien does not exude great confidence in their chances of winning the war. Rather, she remains ambiguous about what she considers to be the likely outcome of the conflict. On the one hand, O'Brien entitles her chapter on Madrid with the Republican battle-cry "No pasarán" (They [i.e. the Nationalists] shall not pass [into Madrid]) and prophesies that the embattled capital of Spain will not surrender to "the enemy of all that is individualistic, free and liberta$\operatorname{rian}^{72 "}$. On the other hand, however, the elegiac, melancholy tone of her account

66. Mary Lavelle, op. cit., p. 135.

67. Mary Lavelle, p. 50.

68. Ibid., p. 63.

69. Ibid., 159.

70. Ibid., 161.

71. Ibid., p. 164-65.

72. FS, p. 102. 
of happy days spent in "gay, leisurely ${ }^{73}$ " Madrid before it was being bombed by the Nationalists betrays the writer's doubts as to the besieged madrileños' chance of holding out much longer. Similarly, the writer's hope that the noble qualities of the Spanish people might enable them to emerge invigorated from their current ordeal and provide future generations with a working model of "a gentlemanly, anarchical system founded on man's supposed predisposition to sanity" is immediately belied in her next statement: "But this is the twentieth century and no one believes any longer - not even the slow, reflective Spaniards - that we are sane $e^{74}$."

In fact, the ambiguity expressed in O'Brien's contradictory prognoses for the future of Spain is already encapsulated in her book's title: Farewell Spain can be read both as a final, definite good-bye bespeaking the writer's fear that the war will change the country beyond recognition, and - in its most literal sense - as a temporary leave-taking expressing her hope that Spain will 'fare well' and overcome the present turmoil relatively unscathed. The book's concluding words - Arriba, España! - are no less ambivalent. What was seemingly intended as an encouraging exhortation to the Spanish Republicans to hold out against their enemies was actually the battle-cry of the Nationalists. Walshe regards O'Brien's use of this slogan as the heading of a chapter in which she denounces Franco as "unfortunate 75 ", while a contemporary reviewer for the Spectator sees it as evidence of her wavering support for the Republican Popular Front government ${ }^{76}$. Yet, it is feasible that she deliberately employed it to convey her doubts about a Republican victory and her vacillation between hope and despair ${ }^{77}$.

Ultimately, the generic category of Farewell Spain is just as hard to pinpoint as its message concerning the future of Spain and Western civilisation in general. The book operates on two levels - on the one hand, it is a highly personal and sentimental travel account written for the author's own nostalgic pleasure on the, other hand, the author's comments on the Spanish Civil War turn Farewell Spain into a travelogue with a political agenda that of defending Spain's democratic left-wing government while promoting absolute anarchy as a desirable utopian alternative to all forms of organised state power. To save her book from being dis-

73. FS, p. 83.

74. FS, p. 154.

75. Eibhear Walshe, op. cit., p. 71.

76. "Miss O'Brien states her political views on the Spanish conflict clearly, a trifle glibly; but one of her chapters is entitled 'No pasarán', another 'Arriba, Espana!" and the reader cannot help suspecting that the tragedy of the civil war distresses her too deeply for full conviction in her chosen cause" (John Marks, "Crumbling Castle in Spain”, Review of Kate O’Brien's Farewell Spain, The Spectator, 27 Aug. 1937, p. 357).

77. O'Brien's equivocal statements might be seen as a result of "the experience of anxiety", which, according to Schweizer, also "had a destabilizing effect on [the] ideological discourses" of other travel writers of the 1930s: "the more anxious they are, the more their discourse of travel begins to fold into ambivalence" (Bernard Schweizer, Radicals on the Road. The Politics of English Travel Writing in the 1930s, Charlottesville, UP of Virginia, 2001, p. 146-147). 
missed by Franco sympathisers as "Red" propaganda, she emphasises its highly personal nature by casting herself in the role of the pining lover who cannot bear the thought of aspersions, let alone bombs, being cast on her treasured Spain and wields her pen in Spain's defence against ignorant tourists, foreign travel writers perpetuating old clichés, and Fascists assailing the democratically elected leftwing Republican government; she keeps her political commentary short and refrains from overtly repudiating the pro-Nationalist propaganda which succeeded in mobilising the masses in Ireland in Franco's favour. Yet, she is indirectly responding to it when she subtly undermines Franco's image as a Catholic Crusader by referring to the Moorish troops in his army, points out the basic similarities between Catholicism and Communism, and stresses her own religiousness in order to demonstrate that Catholic piety is not incompatible with support for the reputedly anti-Christian Spanish government.

Contemporary reviews of Farewell Spain show that the book was indeed primarily read as a travel book. J. L. Ross and the anonymous reviewer for the Dublin Magazine commended the book for its vivid portrayal of "old", disappearing Spain and did not mention her political commentary at all ${ }^{78}$. The reviewers for the Spectator, John Marks ${ }^{79}$, and the Bulletin of Spanish Studies, N. Young, mainly focused on the quality and reliability of O'Brien's descriptions of Spanish places of interest. The latter, whose comments on the "new Spain, purified by sacrifice and yielding gratefully to discipline" suggest a pro-Nationalist bias, took exception to O'Brien's "pessimism about Spain's future" and her "astonishing opinion that St. Teresa, where she alive, 'would have been to-day on the side of Valencia and Madrid'80". Yet, the reviewer for the pro-Republican left-wing paper Irish Democrat, Hanna Sheehy-Skeffington, judged the book primarily for its political content and praised its 'educative' value for Irish readers: "I would like to see this book [...] read by [O'Brien's] countrymen and women throughout Ireland, many of whom are still in darkness as to the realities in Spain ${ }^{81}$." Even half a century later, in 1985, Mary O'Neill, who had accompanied the author on her trip to Spain in 1935, introduced Farewell Spain in her preface to the book as "not really a political book", but "a book of reminiscence, of nostalgic pleasure, of regret for something perhaps never to be experienced again ${ }^{82 "}$. In her recent monograph Kate O'Brien and the Fiction of Identity, Aintzane Legarreta Mentxaka has noted a "general determination" among scholars "to de-politicise O'Brien's

\footnotetext{
78. J. L. Ross, Review of Farewell Spain. Ireland To-day, n 2, Sept. 1937, p. 83; Anon., Review of Kate O’Brien's Farewell Spain, The Dublin Magazine, n 13, Jan. 1937, p. 64.

79. John Marks, op. cit., p. 357.

80. N. Young, Review of Kate O'Brien's Farewell Spain. Bulletin of Spanish Studies, n 14, Oct. 1937, p. 218.

81. H. S. Skeffington, "St. Teresa Would Back Madrid", Irish Democrat, 16 Oct. 1937, p. 2.

82. Mary O’Neill, op. cit., p. XIII.
} 
work" also manifesting itself in the critical commentary on Farewell Spain, whose political content has been "invariably neutralised" and "rarely specified". To Mentxaka, though, "Farewell Spain [...] is clearly an attempt to offer a favourable witness account of the causes and development of the civil war in the face of hostile propaganda ${ }^{83}$ ".

Despite the critical tendency to ignore or play down the travel book's political import, various commentators have suggested that O'Brien's fierce criticism of Franco in Farewell Spain led to her being banned from entering Spain until $1957^{84}$. However, as Morales has stated in her paper on O'Brien's encounters with Spanish censorship, no documentary evidence of the author ever having been denied entry into Franco's Spain has been traced so far. Nor is there any record of Farewell Spain having been censored in Spain or of any requests for permission to publish a Spanish translation having been submitted to the authorities ${ }^{85}$. Walshe's suggestion that "there would have been no official Nationalist censorship in place to ban $\mathrm{it}^{86 \text { " }}$ during the Spanish Civil War is questionable; the proNationalist Irish journalist Francis McCullagh reported on the rigid censorship which foreign journalists' press articles were subjected to in Nationalist Spain in his eyewitness account of the Spanish Civil War ${ }^{87}$. It is more likely a case of selfcensorship, i.e. the publication of Farewell Spain was probably not even attempted during the war, let alone during the Franco's dictatorship ${ }^{88}$. O'Brien finally managed to return to her beloved Spain in 1958 "by legal means ${ }^{89}$ ". But even in the years of absence Spain continued to constitute a fertile source of inspiration for the author. In 1946 she published That Lady, a highly successful novel set in $16^{\text {th }}$ century Spain and offering a critique of authoritarian regimes also relevant to

83. Aintzane L. Mentxaka, op. cit. p. 51.

84. E.g. Lorna Reynolds, op. cit., 97; Butler de Foley, op. cit., p. 24, O’Neill, p. Xii; Eibhear Walshe, op. cit., 76.

85. Marisol Morales Ladrón, "Banned in Spain? Truths, Lies and Censorship in Kate O’Brien's Novels", Atlantis, $\mathrm{n}^{\circ} 32$, June 2010, p. 57-72.

86. Eibhear Walshe, op. cit., p. 75.

87. Francis McCullagh, In Franco's Spain: Being the Experiences of an Irish War-Correspondent during the Great Civil War which Began in 1936, London: Burns Oates \& Washbourne, 1937.

88. O'Brien's claim in a lecture in March 1972 that she was never "persona grata with the Franco government" and that "it [was] the only feather in [her] cap that all [her] works [had] been long ago banned in Spain" (Canterbury lecture, op. cit., 4) was clearly wrong. But so is Walshe's contention that "her work was freely available in Spain" and that " $[\mathrm{t}]$ he only form of censorship recorded was that permission was refused for the book jacket of Without My Cloak on the grounds of immorality!" (Eibhear Walshe, op. cit., 75). In fact, permission to translate Mary Lavelle was denied on 7 January 1944, without any reasons being specified (Archivo General de Administración de Alcalá de Henares, expediente no. 8102-43). Moreover, the translation of The Last of Summer (Final de verano in Spanish) was only authorised on 15 June 1943 on condition that all 'immoral' as well as all critical statements on Hitler and Nazi-Germany would be excised or paraphrased (ibid., expediente no. 3852-43).

89. Mentxaka notes that an official stamp from the Spanish border officials of 2 Sept. 1954 indicates that O'Brien "had managed at least once to cross the border without adequate documentation" and "see[s] no reason to doubt that her visa was denied a number of times after 1947, possibly even for a decade until 1957" (op. cit., p. 216). 
the Franco dictatorship, and in 1951 she brought out a biography of Saint Teresa of Ávila; her last, unfinished novel Constancy was again partly set in Spain. Moreover, she contributed travel pieces to British and Irish newspapers and gave talks about Spain to various associations from the late 1950s to the early $1970 \mathrm{~s}^{90}$.

Even if O'Brien succeeded in selling Farewell Spain as a sentimental travel book rather than a political pamphlet to her reviewers/critics, the present analysis has shown that the text's political tenor is in fact hard to overlook, not solely on account of the author's remarkably explicit statement in favour of Spain's leftist Republican government. For, much like W. H. Auden and Louis MacNeice in their travel book Letters from Iceland, O'Brien made it quite obvious to her readers in Farewell Spain that the escapism which she advocates "is no longer possible" in the troubled 1930s given "the generation's inescapable involvement in its time and in contemporary European disasters ${ }^{91}$. Therefore, her book represents another prime example of Paul Fussell's observation that "the Spanish War effectively ended travel to Spain, and the former Hispanic travel book turn[ed] perforce into the Spanish war book ${ }^{92 ”}$.

90. Walshe, op. cit., p. 75.

91. Samuel Hynes, The Auden Generation. Literature and Politics in England in the 1930s, $2^{\text {nd }}$ edition, London, Pimlico, 1992, p. 289.

92. Paul Fussell, op. cit., p. 216. 